\section{Property rights and reputation in the dairy agro-industrial system}

Property
rights and
reputation

\author{
Carolina Andrea Gómez Winkler Sudré and José Paulo de Souza \\ Universidade Estadual de Maringá, Maringá, Brazil, and \\ Melise Dantas Machado Bouroullec \\ École d'ingénieurs de Purpan, Toulouse, France
}

\begin{abstract}
Purpose - The purpose of this study is to understand the effect of governance structure alignment, property rights protection, and reputation in generating efficiency in dairy agro-industrial system in Paraná, Brazil, and Midi-Pyrénées, France.

Design/methodology/approach - Descriptive qualitative research, comprising semi-structured interviews with producers, processors and key agents of the dairy agrindustrial system in Brazil and France, in 2016/2017.

Findings - As a result, it was identified that measurement generates information about transacted dimensions and when it is shared can generate affect reputation in transactions that leads to system improvement. It was also observed that, in the dairy agro-industrial system, reputation acquired does not reduce all the measurement costs, as the product requires measurement in each all collection, regardless of the reputation created.
\end{abstract}

Research limitations/implications - As a limitation of the study, there is a difference in the moments when the interviews were done. In 2016, in France, the context was low prices, while in 2017, in Brazil, there was a rise in prices. This difference could have influenced some responses to the interviews, mainly about efficiency by producers.

Practical implications - Reputation, protecion of property rights by measurement and information sharing allows reduction costs (transaction, measurement and negotiation costs). This efficiency implies improvement to the system, in cases of milk producers and processors.

Social implications - Improvements in the dairy system can have repercussions on several other improvements such as better distribution of income among agents in the chain; better-paid producers, which implies the improving quality of lives of these people; better products offered to consumers.

Originality/value - From a complementary perspective of transaction cost economics and measurement cost economics, reputation and protection of property rights are discussed with a focus on efficiency. Empirically, the paper contains heterogeneous data collected from two countries: Brasil and France.

Keywords Measurement, Reputation, Property rights, Governance structure,

Dairy agro-industrial system

Paper type Research paper

(C) Carolina Andrea Gómez Winkle Sudré, José Paulo de Souza and Melise Dantas Machado Bouroullec. Published in RAUSP Management Journal. Published by Emerald Publishing Limited. This article is published under the Creative Commons Attribution (CC BY 4.0) licence. Anyone may reproduce, distribute, translate and create derivative works of this article (for both commercial and non-commercial purposes), subject to full attribution to the original publication and authors. The full terms of this licence maybe seen at http://creativecommons.org/licences/by/4.0/legalcode

This research was funded by Coordenação de Aperfeiçoamento de Pessoal de Nível Superior (CAPES). The authors acknowledge the support of the Département Sciences Economiques et Sociales of the École d'Ingénieurs de PURPAN. Authors are grateful to the anonymous referees for the contributions.
Received 14 July 2020 Revised 26 October 2020

15 January 2021

24 February 2021

19 April 2021

Accepted 17 May 2021

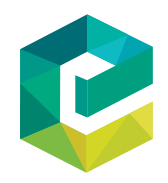

RAUSP Management Journal Vol. 56 No. 4, 2021 pp. $425-443$

Emerald Publishing Limited 2531-0488 DOI 10.1108/RAUSP-07-2020-0145 
RAUSP

56,4

\section{Introduction}

The central idea that runs through this article concerns the generation of efficiency through governance structure alignment, property right protection and reputation among agents of the dairy agro-industrial system (AGS). For this, transaction cost economics (TCE) and measurement cost economics (MCE) offer complimentary theoretical support for achieving efficiency. To TCE, efficiency is generated by minimizing opportunistic attitudes through governance structures aligned with asset specificities (Williamson, 1985). By MCE, efficiency is obtained through property rights protection by measurement (Barzel, 2005). Thus, considering transaction characteristics and governance choice, an efficient structure interacts to limit ex-post opportunistic attitudes that enable reputation creation on ongoing relationships (Williamson, 1985).

When attributes and dimensions transacted are identified and measured and resulting information is shared between agents, economic rights losses are reduced (Barzel, 2001). As consequence, the reputation among agents is increased and robust conditions for value distribution are created. Barzel (2005, p. 368) claims that "[ . . . ] firms may acquire reputation not engaging in capturing the quasi rent." This is due to the alignment between attributes and dimensions transacted with the governance structure adopted (Williamson, 1985; Barzel, 2005). It is important to note that the MCE view considers the ex-ante selection of institutional forms to mitigate the agent's maximization behavior ex-post (Langlois, 1992).

The complement of TCE and MCE has already been used in other studies (Pereira, Bánkuti, Pereira, \& Souza, 2016; Augusto, Souza, \& Cário, 2017; Guimarães \& Bánkuti, 2019), ratifying Williamson's (1985, p. 29) proposition that "Both, however, are important and in fact are interdependent." Both share the same bases but differ in key variables, explicit assumptions and internal logic (Zylbersztajn, 2018). As a contribution, this study seeks to advance in understanding how, in a complementary way, the governance structure alignment predictions generate efficiency and performance, considering property rights and reputation. Together, property rights protection through measurement and the reputation built on the relationship, contribute to the chain efficiency and, consequently, in its development. Recent theoretical developments have been made in this direction (Ménard, 2018a, 2018b).

Considering costs involved, mainly those associated with agents' contractual relationships, the focus is the transaction costs related to measurement, which affects the agents' performance, provided by Barzel (2005), interacting with transaction costs economics. These costs involve the measurement of transacted dimensions, the reputation built on the relationship and the protection of property rights. It is predicted that measurement efficiency and reputation enhance property rights protection in agent's transactions when several stages of production are present. As Langlois (1992, p. 102) stated "[...] Barzel has provided a more general theory of how measurement costs affect organizational form."

Contributing to other writers that interact with TCE and MCE, the objective of the present study is to understand the effect of governance structure alignment, property rights protection and reputation in generating efficiency in dairy AGS in Paraná, Brazil and MidiPyrénées, France.

Milk, the object of this study, is a universal food, consumed for 12.000 years and has gained development in industrial procedures, improving its conservation and transport, which guarantees its quality (Maison Du Lait, 2016). So, "In many parts of the world, milk and dairy products are highly valued and have an important role in both household food security and also in income generation” (FAO. Food \& Agriculture Organization, 2013, p. 7). 
Besides, milk is an important raw material for the food industry, with between 8.000 and 10.000 different types of milk products around the world (Popescu \& Angel, 2009).

The focus is on the dairy AGS in Paraná, Brazil and in the old Midy-Pyrénées region (today called Occitanie), in France. In 2017, Brazil produced 35.7 million tons of cow's milk, with a yield of $1.861 \mathrm{~kg} / \mathrm{cow} /$ year, while France produced 25 million tons of cow's milk, with a yield of $6.953 \mathrm{~kg} / \mathrm{cow} /$ year (CNIEL - Centre National Interprofessionnel de l'economie laitière, 2019). Brazil's production was higher than France's, however, Brazillian milk yield was significantly lower and also lower than world yield, verified at $2.543 \mathrm{~kg} / \mathrm{cow} / \mathrm{year}$ (CNIEL - Centre National Interprofessionnel de l'economie laitière, 2019). These numbers confirm the advance of milk production in France and the need to develop and improve milk production in Brazil.

Paraná system is one of the most important milk production systems in Brazil, having greater productivity. However, as in France, different levels of productivity could be found in the different regions. Besides, while the institutional environment in France defines formal contracts as a governance structure to organize relations (Trouvé, Dervillé, Gouin, \& Pouch, 2014), in Brazil this environment defines rules for product transactions (MAPA Ministério de Agricultura, 2016), without looking at relationship organization. This specificity establishes different conditions for building reputation and protecting value with an effect on the sector's returns, justifying this study. The similarity in terms of diversity and the condition of contracting support the use of the regions for the empirical validation of the proposition.

In addition to its economic importance, the choice of dairy AGS was due to the complexity of transactions. Pereira et al. (2016) identified that in Paraná, measurement and institutional environment do not protect property rights capture and important dimensions are transacted between agents that may be appropriate, characterizing opportunistic behavior conditions. So, this study goes beyond the author's analysis, considering the angle of producers and processors, with data from North, West and Central-Eastern regions of Paraná, the last recognized as a reference in milk production in Brazil. Also, this study considers the governance structure alignment in the search for the protection of property rights and reputation acquirement for generating efficiency, in Paraná and France.

One way to develop and improve milk production (performance) is to improve efficiency through chain coordination. When dealing with vertical organization, the theoretical framework of TCE and MCE offers support for reducing transaction, measurement and coordination costs (Williamson, 1985; Barzel, 2005). The measurement of transacted attributes generates important information for agents to exchanges and their sharing, attached to the protection mechanisms, allows reputation creation by providing appropriate value distribution among agents (Barzel, 2001). Reputation, in turn, is identified as the mechanism that allows transaction continuity, minimizing opportunistic attitudes through shared experiences (Macleod, 2007), enabling competition strategies.

The study with two distinct systems, (in terms of organization, rules and operational and competitive capacities), based on efficiency, aims to identify positive guidelines that can support public and private actions to improve dairy AGS performance, in their origins. Indicative aspects of systems efficacy and their limitations in terms of organizational efficiency, which impacts on results, can serve not only to understand the heterogeneity of the dynamics involved but also to indicate strategic actions. Thus, the study contributes to understanding the effect of reputation on agents in the dairy AGS and can be extended to other production systems. The results identify that efficient arrangements, supported by measurement ratify transaction costs reduction, enhance performance, investments and reputation requirements. 
RAUSP

56,4

\section{Theoretical framework}

\subsection{Governance structure}

For TCE and MCE, the alignment generates savings in transaction costs, with different emphases. While TCE is concerned with quasi-rent protection in an ex-post perspective (Williamson, 1985), for MCE, the focus is property right protection with an ex-ante perspective (Barzel, 2001).

In TCE's view, transaction costs economizing prediction considers transaction attributes and governance structures alignment and its effectiveness in limiting potential opportunistic behaviors among agents (Williamson, 1985). According to the author, the governance structures are market (discontinuous and impersonal); hybrid (formal or informal contracts); vertical integration (internal assets production).

Transaction attributes involve asset specificity, uncertainty and frequency. Asset specificity is the key variable that indicates the appropriate governance structure and involves value loss when the transaction does not materialize or in a contractual breach case (Williamson, 1985). Thus, asset specificity generates quasi-rent (the difference between the value resulting from a specific activity and its best alternate use), which requires an adequate governance structure to coordinate transaction, as agents can dispute for quasi rent appropriation (Williamson, 1985). In this guideline, the adequate governance structure serves as a protection mechanism against these opportunistic behaviors that can occur when a bilateral dependence is created, promoting adaptation of autonomous and cooperative kinds (Williamson, 1985).

In the MCE perspective, an alignment hypothesis can also be inducted. In this case, the principal condition in which transactions differ is related to measurement. Measurement affects organization form or protection mechanisms (Barzel, 2001). As pointed by Barzel (1987, p. 105):

[...] among factors contributing to the value of common effort, the greater the difficulty in measuring one factor's contribution vis-à-vis that of others, the more likely is the owner to that factor to assume the position of the residual claimant.

Thus, as the attributes measurement becomes complex to measure and their costs rise, the use of reputation (long-term relationships) and, at the limit, vertical integration is justified. Contracting is justified when attributes measurement and verification can be established objectively in the contractual clauses (Barzel, 2005). Though, transaction costs arise when the absence of legal apparatus leads to economic rights disputes, in which parties seek to negotiate losses of rights.

\subsection{Measurement and property rights protection}

By protecting property rights in the transaction, besides reducing opportunistic behavior (Williamson, 1985), efficiency is perceived by the more productive choices made by agents, generating a positive impact on economic growth and development (Auerbach \& Azariadis, 2015). Thus, measurement is presented as a monitoring mechanism to generate information about the dimensions of assets transacted, contributing to the protection of property rights (Barzel, 2005). Therefore, information is created by decomposing transactions into measurable dimensions that influence the agreements and enable evaluation and control (Barzel, 2001).

3In this context, measurement is established as an ex-post instrument to enforce agreements between agents. So, property rights indications are defined ex-ante in contractual relationships (which generates transaction costs) to make enforcement mechanisms action feasible. Thus, property rights study is associated with information costs, with a focus on protecting rights related to transaction dimensions (Zylbersztajn, 2018). 
Following the old property rights tradition, Barzel (1994) considers that an individual's property right over resources consists of the right or power to consume, obtain income and dispose of these resources through an exchange. The author distinguishes legal rights and economic rights, considering legal rights as "[...] individuals' rights that the state helps enforce" (Barzel, 2001, p. 4). Economic right, on the other hand, is characterized as the ability to directly consume the asset's services or indirectly through exchange.

In this sense, according to Barzel (1994), the key question about property rights is not on assets possessed by the actors, but what can they do with the attributes of the assets. For Foss and Foss (2001), this occurs, as most assets have several attributes, which cannot be specified and the notion of ownership of assets is vague. As the transaction is expensive and obtaining complete information on the dimensions involved is difficult, property rights are never fully delineated, making space for income capture.

\subsection{Reputation}

Reputation is informal or indirect enforcement, without a third party to arbitrate where punishment can be inflicted instantly. Is related to a person's propensity to keep his promises and is associated with the continuity of transactions (Macleod, 2007). As stated by Williamson (1993), reputation must be acquired in the relationship, enable reducing risks and generate efficient contractual relationships by reducing enforcement costs. Consequently, reputation is sustained by agents when honoring agreements and not engaging in the capture of value (Barzel, 2005).

For Williamson (1993), those who violate contracts and behave opportunistically lose their reputation. When performance is substandard "[...] the seller is punished via the effect of the breach on his future payoff," ending the transaction (Macleod, 2007, p. 602). So, reputation directly influences the frequency of the transaction. According to North (1991), reputation is related to path dependence. The stability of institutions reinforces reputation, reduces information costs and generates potential gains. In that case "[...] adaptative expectations arising from the prevalence of contracting based on the existing institutions" (North, 1991, p. 109). The prevalence of contracting acts as a safeguard in transactions given experiences sharing, reduction of opportunistic behavior and, consequently, in transaction costs (Williamson, 1985).

The measurement and information generated and shared, provide transaction-specific protection in the absence of reputation. Thus, when considering Williamson's (1985) proposition, transaction frequency can generate reputation among agents, in an alignment condition (attributes and governance structure); in the same way for Barzel (2005) reputation is associated with the use of short-term contract (for measurement) and long-term relationships that reduce moral hazard and the need for measurement. Correspondingly, considering that coordination also reduces conflicts in relationships (Farina, 1999), it is possible to present the following propositions:

P1. Path dependence and an appropriate governance structure generate a reputation that, by improving the agent relationship system, increases the frequency of transactions.

P2. Measurement establishes reputation mechanisms (associated with frequency and absence of moral hazard) when it is able to limit the capture of individuals' rights.

P3. Measurement and reputation affect value distribution (guaranteeing property rights through the possession of information on transacted assets) by identifying individual performance (reduction of transaction and measurement costs and increasing returns). 
RAUSP

56,4

430

\section{Methodological procedures}

The proposition was analyzed under a qualitative descriptive cross-sectional research. Primary data were collected by semi-structured interviews with producers, processors and two key agents in the dairy chain (a researcher in milk and dairy products and a moderator at Livestock Institute, in France). The selection of respondents was made by availability and convenience, considering the regions surveyed and the interviewee's acceptance. Secondary data were used to characterize and understand the production system in the surveyed regions, in both countries. The secondary data sources were: National Interprofessional Center of Dairy Economics (CNIEL), National Establishment of Agricultural and Seafood Products (FRANCEAGRIMER), Agreste figures and data, National Supply Company (CONAB), Paraná Institute of Economic and Social Development (IPARDES), Secretary of State Agriculture and Supply (SEAB/DERAL) and related articles in France and Brazil.

In Paraná, the interviews were conducted in three regions: Central-Eastern, Western, the most developed regions in the chain and the North, one of the least dairy producing regions (IPARDES. Instituto Paranaense de Desenvolvimento Econômico e Social, 2009). The triangulation of data allowed us to propose inductions related to the propositions and the productive, technological and management diversity, enabling regional specificities identification. In France, the interviews were done in the old Midi-Pyrénées, southwest of the country, which also has different levels of development in the chain. In such a region, Aveyron is more specialized and accounts for $39 \%$ of regional production and other less specialized regions account for approximately 5\% of regional production (DRAAF Midi-Pyrénées, 2013). Data processing was done by full transcription of the recorded interviews and the use of NVivo Pro software, in which the information was organized in source classification worksheets and coded according to the pre-established analysis categories (Figure 1). Data analysis and

Figure 1.

Analysis categories

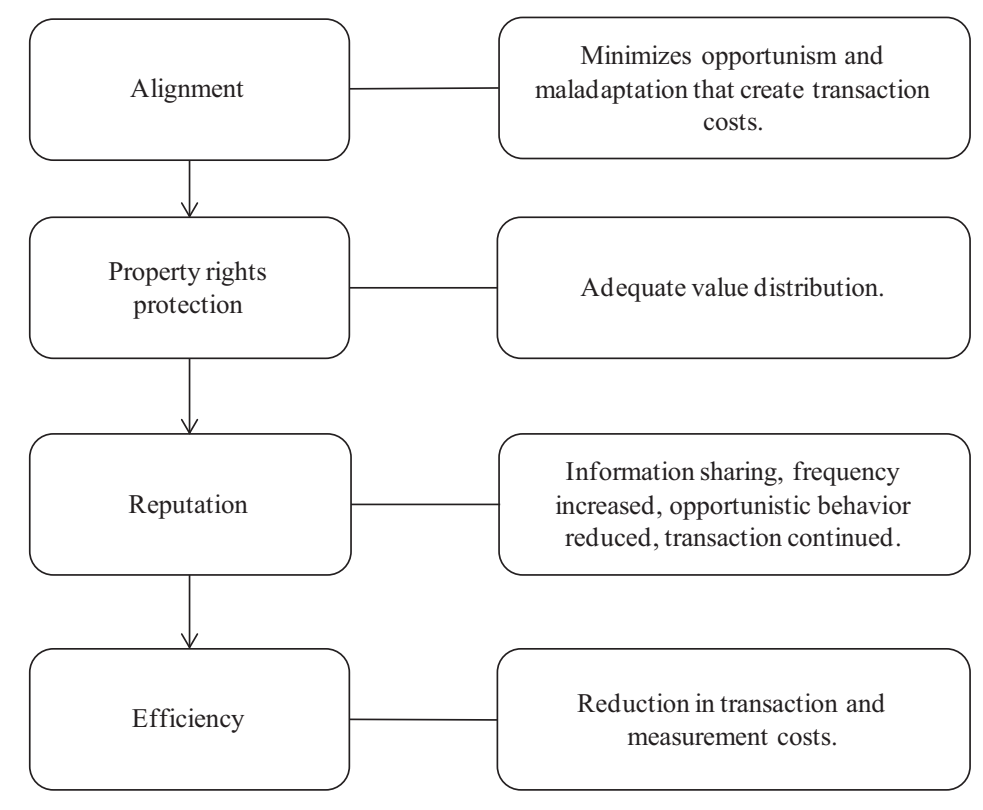

Source: Elaborated by the authors 
interpretation were done through qualitative content analysis, following the steps proposed by Moraes (1999): information preparation; unitarization or transformation of content into units; categorization or classification of units into categories; description; interpretation.

To generate validity and reliability on core predictions analysis, the research considers data triangulation taking several sources (primary data; statements of key agents from AG consultation; secondary data), treated based on the theoretical review.

\section{Data presentation and analysis}

\subsection{Profile of respondents}

The profile of interviewed producers in France and Brazil is presented in Table 1. Table 2 shows the characteristics of the processors interviewed in both countries.

\begin{tabular}{|c|c|c|c|}
\hline Producer* $^{\text {T }}$ & $\begin{array}{l}\text { milk pro } \\
\text { (years) }\end{array}$ & $\begin{array}{l}\text { production p } \\
\text { (liters/day) }\end{array}$ & Governance structure \\
\hline 1 & 35 & 24 & Contract and integration \\
\hline 2 & 38 & 25 & Contract \\
\hline 3 & 10 & 25 & $\begin{array}{l}\text { Tacit agreement (informal contract) } \\
\text { and integration }\end{array}$ \\
\hline 4 & 21 & 27 & Tacit agreement (informal contract) \\
\hline 5 & 30 & 30 & Contract \\
\hline 6 & 17 & 23 & Contract \\
\hline 7 & 41 & 23 & Contract \\
\hline 8 & 7 & 27 & Contract \\
\hline 9 & 5 & 15 & Tacit agreement (informal contract) \\
\hline 10 & 5 & 20 & $\begin{array}{l}\text { Tacit agreement (informal contract) } \\
\text { and integration }\end{array}$ \\
\hline 11 & 8 & 18 & Contract \\
\hline 12 & 20 & 21 & Contract \\
\hline 13 & 5 & 19 & Contract \\
\hline 14 & 25 & 31 & Contract \\
\hline 15 & 17 & 22 & Contract \\
\hline 16 & 25 & 20 & Contract \\
\hline 17 & 10 & 24 & Contract \\
\hline 18 & 40 & 20 & Tacit agreement (informal contract) \\
\hline 19 & 30 & 22 & Tacit agreement (informal contract) \\
\hline
\end{tabular}

Source: Elaborated by the authors from primary data. * 1-8 France; 9-19 Brazil

Table 1.

Characteristics of producers interviewed

\begin{tabular}{lccl}
\hline Country & Processor & Producers suppliers & Type of company \\
\hline FR & 1 & 2,300 & Cooperative \\
FR & 2 & 400 & Industry \\
BR & 3 & 130 & Industry \\
BR & 4 & 369 & Cooperative \\
BR & 5 & 1,000 & Cooperative
\end{tabular}

Source: Elaborated by the authors from primary data

Table 2.

Characteristics of processors interviewed 
RAUSP

56,4

432

\subsection{Governance structure alignment in Paraná}

In Paraná (Central-Eastern and Western regions), specific assets transacted (site-specificity, temporal specificity and physical assets) are aligned with a formal contract, as a governance structure. This alignment is based on the assumptions of TCE (Williamson, 1985) and MCE (Barzel, 2001). Measurable specific dimensions (volume, bacteria, somatic cells, temperature, fat, protein, cryoscopy, capacity or flexibility of storage in the property, accreditation of good practices on the farm, access to the property) and their impact on price, whether in bonuses or discounts, are defined in a booklet which confirms the enforcement by contract and low opportunism risk.

Identified verbal agreements (Western and Northern regions) indicate that there is no alignment on the TCE and MCE assumptions. This increases the possibility of opportunistic behavior, generating transaction costs in case of the retest in milk evaluation by the agents, ratifying Williamson (1985). Also, although measurement information is generated, there are difficulties in obtaining protection from the state from the producer side, given that only economic rights are present and they depend on negotiation, which is not always positive. The governance structure used and their analysis is shown in Table 3.

\subsection{Property rights and reputation in Paraná}

In the Central-Eastern region, the proposition that property rights protection occurs from measurement and information sharing (Barzel, 2001) is convergent to empirical data. The alignment between governance structure (formal contract) with the assumptions of TCE (Williamson, 1985) and MCE (Barzel, 2001, 2005) promotes reputation among agents (Macleod, 2007) and product value is distributed. It was empirically identified that measurement is performed by a third party continuously and information is shared between producers and processors, which makes it possible to protect property rights. Therefore, the contract guarantees the additional price for product dimensions (legal right), encouraging the production of quality milk in the region. The quality is considered a legal right, in terms of Barzel's proposition. That's because the measurable dimensions related to quality and how it will be encompassed by the price established in the contract (formal or informal). However, as the price is given by the buyer, based on a base price, its enforcement has to be negotiated (economic right).

Thus, the relationship between measurement (Barzel, 2001) and reputation (Macleod, 2007) was observed by all producers interviewed in the region, when considering that

\begin{tabular}{|c|c|c|c|}
\hline $\begin{array}{l}\text { Governance } \\
\text { structure }\end{array}$ & TCE & MCE & Effect \\
\hline $\begin{array}{l}\text { Formal } \\
\text { contract }\end{array}$ & $\begin{array}{l}\text { Alignment (presence } \\
\text { of idiosyncratic } \\
\text { attributes) }\end{array}$ & $\begin{array}{l}\text { Alignment (clearly defined } \\
\text { dimensions and objectivity of } \\
\text { measurement, with low cost) }\end{array}$ & $\begin{array}{l}\text { Possibilities of opportunistic } \\
\text { behavior are reduced due to the } \\
\text { protection of legal rights } \\
\text { Production of superior quality milk }\end{array}$ \\
\hline $\begin{array}{l}\text { Informal } \\
\text { contract }\end{array}$ & $\begin{array}{l}\text { Non-alignment } \\
\text { (specific asset } \\
\text { existence) }\end{array}$ & $\begin{array}{l}\text { Non-alignment (objective } \\
\text { measurement) }\end{array}$ & $\begin{array}{l}\text { Mistrust in the relationship } \\
\text { Minimum investments in } \\
\text { production } \\
\text { Minimum quality milk }\end{array}$ \\
\hline
\end{tabular}

Governance structure and effects in Paraná

Source: Elaborated by the authors from primary data 
measurement generates trust in the relation. Furthermore, the confidence in the relationship is recognized in the evaluation that producers made of the processor. On a scale from zero to ten, seven as a minimum score was pointed out by interviewees. Path dependence also was highlighted, as evidenced by North (1991) and was empirically identified in the relationship, which contributes to system improvement. It is observed that measurement and information sharing reduce opportunistic attitudes related to possibilities of income appropriation, regarding values of milk dimensions (legal right). It is also noted that recurring frequency is established by contractual conditions but also enhances reputation.

Besides, producers' reputation is also highlighted, ratifying Williamson (1993) that reputation has to be acquired. The interview convergence revealed that reputation is generated by the transparency that exists in the relationship and information sharing that allows the reduction of possible opportunistic behaviors. Besides, it can be asserted that the continuity of transactions, related to frequency, is also a reflection of the reputation created.

Empirically, it was not verified that reputation decreases all measurement costs. This can be justified by milk characteristics, which have variability in evaluation results. Besides, the high possibility of sanitary problems in its dimensions demands strict control. When comparing to other regions of Paraná, however, there were no reports of retests execution, which reduces transaction costs by double measurement, mainly by producers. Although measurement, in all milk collections, is necessary to protect agents' property rights. In short, it is observed that reputation reduces transaction costs, as opportunistic attitudes are limited and double measurement (Barzel, 2005) is not mentioned.

In this sense, it was induced that reputation, associated with path dependence, recurring frequency and governance structure alignment with attributes and dimensions (TCE and MCE), leads to system improvement. It can be identified by the national representativeness that the region's milk production has in terms of productivity and product quality (SEAB/DERAL, 2019), which demonstrates empirically what Auerbach and Azariadis (2015) claim about the system development. The statement of reinvestments in the activity by interviewed milk producers ratifies this notion.

In the West and North regions of Paraná (verbal agreement cases), the protection of property rights is limited. Measurement is made by a third party, continuously and results are shared, but respondents do not believe in these results from the processor's lab. As an example of distrust, Producer 18 claimed to have done a retest and the results of the same sample were different from the results of the buyer's lab. Thus, reputation was not identified as a consequence of measurement. However, in the West region, producers claim to trust the processor because it is cooperative and payments are always made.

It was observed in the interviews that measurement did not influence reputation, as reports of unreliable results put the producer on alert. As reported, reputation comes from path dependence (North, 1991). In this case, path dependence and reputational capital reinforce the stability of the relationship. Although there is no doubt about the payment, the governance structure is not sufficient to limit opportunistic attitudes (unpaid dimensions) and the measurement results are not reliable, say interviewed producers. As consequence, transaction costs are higher (retests cases have been identified) due to negotiation possibilities and the greater potential for opportunistic attitudes (unpaid dimensions), which is consistent with TCE and MCE.

\section{Property rights and reputation}


RAUSP

56,4

It can be inferred that the fact of a formal contract does not exist puts a large part of the transaction under economic rights protection, just as Barzel (2005) predict, which reduces the potential for generating reputation. Also, the history of measurement errors limits this possibility, although confidence payment is effective. The uncertainties associated with milk variability, inherent to the activity, in turn, allows the persistence of this form of governance structure (informal contract).

According to the interviewed producers, measurement helps in negotiations with the processors. Despite this, the reputation was not identified in the North region. Thus, it is clear that reputation is not identified due to the lack of property rights protection, (legal and economic rights) to producers. It is observed that the lack of guarantee of rights also negatively impacts the income distribution in the chain, ratifying Barzel (2005) and Williamson (1985). According to producers, with the milk income, it is not possible to reinvest in milk production.

In this sense, it is noted that by not observing the reduction of opportunistic attitudes and property rights protection, the reputation is not verified, which reinforces the main statement proposed. Despite the sharing of information, this is not reliable by producers. Accordingly, property rights are not protected, as pointed out by Barzel (2005). As consequence, quality milk production is not encouraged. The absence of alignment between the transacted attributes and governance structure and the existence of economic rights not well defined, make governance structure inefficient. Transaction costs are thus generated, due to the need for double measurement and the need for negotiation (ex-post costs).

It is observed that the small number of processors reduces possibilities for producers to transact with reliable buyers, who consider quality in the payment of the product. No reductions in transaction costs were identified, as the governance structure does not limit the possibilities for opportunistic attitudes and there are negotiation costs, beyond the additional measurement costs for carrying out retests, just as Williamson (1985) and Barzel (2005) predicted. Table 4 presents the highlights from the interviews and their analysis.

In the Central-Eastern region, theoretical propositions are empirically evidenced, as formal contracts protect legal rights over milk properties and measurement generates information that favors the protection of property rights. Besides, reputation is created by the trust generated in the frequency of the relationship and some positive effects are identified such as reduced coordination costs, milk production with superior quality, continuity in the relationship and reinvestments in production. In the West region, reputation is created by path dependence and the relation with cooperatives (history of payment reinforces stability in the relationship) and in the North region, reputation is not created. In these two last regions, respondents stated that they were unable to invest in production. This analysis is summarized in Table 5.

\subsection{Governance structure alignment in the old Midi-Pyrénées}

In France, Williamson's alignment prediction was observed. Supported by the institutional environment, a medium level of specific assets (site, temporal and human specificity) are transacted under formal contract governance. This alignment, in turn, is supported and justified under the assumptions of TCE and MCE (Williamson, 1985; Barzel, 2001, 2005) propositions. The dimensions are defined in the contract (fat, protein, bacteria, cells, germs, antibiotics and butter content) and measurement cost is low, divided between producers and processors interviewed. 


\begin{tabular}{|c|c|c|c|}
\hline $\begin{array}{l}\text { Agents } \\
\text { interviewed }\end{array}$ & Region & Highlights & Reduced analysis \\
\hline Producer 15 & Central-Eastern & $\begin{array}{l}\text { "My relationship with the cooperative only } \\
\text { stimulates me. It gives me security in my } \\
\text { investments, I'm not afraid; if I were alone I } \\
\text { know that I would be more vulnerable" }\end{array}$ & $\begin{array}{l}\text { Reputation created } \\
\text { between agents }\end{array}$ \\
\hline Processor 04 & & $\begin{array}{l}\text { "From the point of view of supply, I give nine. I } \\
\text { trust them that there will be no shortage of milk } \\
\text { in the industry, that the rules are being complied } \\
\text { with, in this regard they are readiness" }\end{array}$ & \\
\hline Producer 10 & North & $\begin{array}{l}\text { "Measurement does help. You can talk about } \\
\text { very concrete things, it is very vague without } \\
\text { analysis. Before, what was concrete was the } \\
\text { number of liters I delivered and how much the } \\
\text { buyer paid me. Now we have the analysis for us } \\
\text { to base it on" }\end{array}$ & $\begin{array}{l}\text { Measurement } \\
\text { generates trust in the } \\
\text { relation }\end{array}$ \\
\hline Producer 16 & West & $\begin{array}{l}\text { "Measurement generates confidence, for sure. If } \\
\text { we trust, we see that the activity is serious and } \\
\text { we continue" }\end{array}$ & \\
\hline Producer 12 & Central-Eastern & $\begin{array}{l}\text { "Measurement helps, it's important. If you have } \\
\text { any suspicion, you can also have a retest. They } \\
\text { store the sample and if we have any questions, } \\
\text { they analyze it again" }\end{array}$ & \\
\hline Producer 17 & West & $\begin{array}{l}\text { "The cooperative, we know that every month we } \\
\text { will receive our payment" }\end{array}$ & $\begin{array}{l}\text { Reputation is created } \\
\text { by path dependence }\end{array}$ \\
\hline Producer 18 & & $\begin{array}{l}\text { "Until today I never had a problem with } \\
\text { payment, the cooperative has always paid us up } \\
\text { to date... Our buyer was never late. He is not } \\
\text { the one who pays the best, but he is the one who } \\
\text { always pays. We have that confidence" }\end{array}$ & \\
\hline Producer 10 & North & $\begin{array}{l}\text { "In the relationship with the processor, there is a } \\
\text { lack of transparency, an open game ... They } \\
\text { say that they pay the same for everyone, but } \\
\text { when we talk to producers, we see that it is so } \\
\text { not. We need to negotiate more seriously" }\end{array}$ & $\begin{array}{l}\text { Reputation is not } \\
\text { created }\end{array}$ \\
\hline Producer 09 & & $\begin{array}{l}\text { "Our situation today is unsatisfactory. Here, in } \\
\text { our region, nobody can negotiate. When there is } \\
\text { a problem in the evaluation of our milk, we } \\
\text { suspect and do the counter test" }\end{array}$ & \\
\hline Producer 09 & North & $\begin{array}{l}\text { "With milk income, I cannot reinvest, nor do I } \\
\text { encourage myself to continue in the activity" }\end{array}$ & Fewer investments \\
\hline Producer 19 & West & $\begin{array}{l}\text { "We have already gone through a lot of financial } \\
\text { difficulties, including a year ago we took money } \\
\text { out of our pockets, from saving to stop. Every } \\
\text { month I have something pending which makes } \\
\text { it difficult to invest" }\end{array}$ & \\
\hline
\end{tabular}

"My relationship with the cooperative only stimulates me. It gives mesecurity in my know that I would be more vulnerable" "From the point of view of supply, I give nine. I trust them that there will be no shortage of milk in the industry, that the rules are being complied with, in this regard they are readiness" very concrete things, it is very vague without analys. Before, what was concrete was the buyer paid me. Now we have the analysis for us to base it on" we trust, we see that the activity is serious and they analyze it again" will receive our payment" payment, the cooperative has always paid us up to date ... Our buyer was never late. He is not the one who pays the best, but he is the one who always pays. We have that confidence" lack of transparency, an open game ... They say that they pay the same for everyone, but we talk to producers, we see that it is so not. We need to negotiate more seriously" a problem in the evaluation of our milk, we suspect and do the counter test" encourage myself to continue in the activity" " have already gone through a lot of financial out of our pockets, from saving to stop. Every it difficult to invest”
Table 4.

Highlights and analysis from interviews in Paraná

Source: Elaborated by the authors from primary data

In complement, primary and secondary data indicate that this governance structure is mandatory, established by the institutional environment to regulate transactions (Trouvé et al., 2014). According to the authors, a formal contract became mandatory in 2015, with a five years term. Thus, the contract sets the price determination mode considering the quality 
RAUSP

56,4

\begin{tabular}{|c|c|c|c|}
\hline Region & $\begin{array}{l}\text { Property rights } \\
\text { protection }\end{array}$ & Reputation & Effect \\
\hline Central-Eastern & $\begin{array}{l}\text { Formal contract, } \\
\text { measurement, } \\
\text { institutional rules and } \\
\text { information sharing }\end{array}$ & Created & $\begin{array}{l}\text { Reduction of coordination } \\
\text { costs } \\
\text { Continuity of the relationship } \\
\text { Quality milk production } \\
\text { Reduction of opportunistic } \\
\text { attitudes } \\
\text { Investments in milk } \\
\text { production }\end{array}$ \\
\hline West & $\begin{array}{l}\text { Informal contract, } \\
\text { measurement and } \\
\text { institutional rules }\end{array}$ & $\begin{array}{l}\text { Created (path } \\
\text { dependence) }\end{array}$ & $\begin{array}{l}\text { Continuity of the relationship } \\
\text { Fewer investments in milk }\end{array}$ \\
\hline North & $\begin{array}{l}\text { Informal contract, } \\
\text { measurement and } \\
\text { institutional rules }\end{array}$ & $\begin{array}{l}\text { Not created (distrust, } \\
\text { a greater potential for } \\
\text { opportunistic } \\
\text { attitudes) }\end{array}$ & $\begin{array}{l}\text { Continuity of the relationship } \\
\text { due to lack of options } \\
\text { Fewer investments in milk } \\
\text { production }\end{array}$ \\
\hline
\end{tabular}
institutional rules

Table 5.

Property rights protection, reputation and effects in Paraná

Source: Elaborated by the authors from primary data

of milk, the volume to be delivered, the collection modalities and the conditions for reviewing and terminating the contract (Trouvé et al., 2014).

Producers 1 and 3, beyond selling milk to processors, also process the milk for sale directly to consumers, adding value to the product. Both producers differentiate their production, with the label bleu blanc coeur and yogurt production (producer 1) and with bio milk and cheese production (producer 3). In these cases, the use of vertical integration, predict by TCE is ratified, considering the increase in asset specificities, according to Williamson (1985). For MCE, the governance structure is not aligned given that measurement costs are not high and the dimensions are specified between agents.

Although the use of contracts is mandatory in France, it is observed that producers 3 and 4 have a tacit agreement with buyers. Producer 3, for direct selling to consumers, delivers to the processor only what is leftover from his production, which is interesting to the buyer due to product differentiation. Producer 4, on the advice of his lawyer, did not sign the contract because the base price of milk is not previously agreed, as he says:

We haven't signed a contract because the price is not established. It has the volume, the quality, but not the price. We try hard to make milk of the established quality, but we don't know the price that will be paid?

Thus, according to the producer, the processor is obliged to collect the milk, even without a contract, as the relationship is old.

Producers 3 and 4 said that they intend to terminate the transaction with buyers, process all the milk and sell directly to the final consumers. The intention is to seek the protection of their property rights and get better financial returns on their products. Failure to protect the base price of milk (economic right) generates mistrust in the relationship and the possibility of opportunistic behavior discourages transaction continuity, which confirms the assumptions of Barzel (2005). The governance structures used and their analysis is shown in Table 6. 


\begin{tabular}{|c|c|c|c|c|}
\hline Governance structure & TCE & MCE & Effect & Property \\
\hline $\begin{array}{l}\text { Mandatory formal } \\
\text { contract }\end{array}$ & $\begin{array}{l}\text { Alignment (specific assets } \\
\text { transacted) }\end{array}$ & $\begin{array}{l}\text { s Alignment (clearly } \\
\text { defined dimensions and } \\
\text { objectivity of } \\
\text { measurement, with low } \\
\text { cost) }\end{array}$ & $\begin{array}{l}\text { Possibilities of opportunistic } \\
\text { behavior are reduced due to } \\
\text { the protection of legal rights } \\
\text { (milk attributes) }\end{array}$ & reputation \\
\hline \multirow[t]{2}{*}{ Vertical integration } & \multirow{2}{*}{$\begin{array}{l}\text { Alignment (increase in } \\
\text { specific assets in the } \\
\text { production of Blue Blanc } \\
\text { Cóur and bio milk }\end{array}$} & \multirow{2}{*}{$\begin{array}{l}\text { Non-alignment } \\
\text { (measurement cost low } \\
\text { and objective control) }\end{array}$} & \multirow[t]{2}{*}{$\begin{array}{l}\text { Investments only in } \\
\text { differentiated milk production }\end{array}$} & 437 \\
\hline & & & & \\
\hline Informal contract & $\begin{array}{l}\text { Non-alignment (specific } \\
\text { asset existence) }\end{array}$ & $\begin{array}{l}\text { Non-alignment (objective } \\
\text { measurement) }\end{array}$ & $\begin{array}{l}\text { Mistrust in the relationship } \\
\text { and discouragement in } \\
\text { transaction continuity }\end{array}$ & $\begin{array}{r}\text { Table } 6 . \\
\text { Governance structure } \\
\text { and effects in the old }\end{array}$ \\
\hline \multicolumn{4}{|c|}{ Source: Elaborated by the authors from primary data } & Midi Pyrónéo \\
\hline
\end{tabular}

\subsection{Property rights and reputation in the old Midi-Pyrénées}

In the old Midi-Pyrénées, property rights are protected by the institutional environment (mandatory contract) which guarantees the additional price for the product quality (legal right), which encourages producers to produce milk with superior quality. The economic rights are observed in the milk base price definition that is made by the processor and is not guaranteed by the contract. Thus, the use of contracts and the lack of economic rights protection do not generate reputation. The lack of property rights protection can favor the producer's rent appropriation (Williamson, 1985) and according to Barzel (2005), the contract reduces the need for reputational capital.

Also, in the milk transaction case, measurement does not generate reputation, as the high possibility of problems per batch does not allow reducing the frequency of measurement, which is required in all batches/collections (by the processor), as empirically identified in the interviews. Thus, this characteristic does not allow the reduction of measurement costs due to the need to control the dimensions. Table 7 presents the highlights and observations identified in the interviews.

For the value distribution among agents in the region, it was observed that the measurement of milk attributes is done by a third party, continuously (three times a month for additional price calculation) and the information is shared between agents. Thus, it was noted that measurement of each product dimension and information sharing act just as Barzel (2005) predicted, limiting opportunistic behavior, reducing transaction costs and ensuring payment for quality milk. Therefore, the appropriating income possibility generated by milk attributes is restricted. Besides, in the region, transaction frequency is high due to contractual clauses and the difficulty that producers have in exchanging buyers. Despite this, the relation between measurement (Barzel, 2001) and reputation (Macleod, 2007), has not been identified, as this has not been confirmed by producers. This context is presented in Table 8.

\subsection{Alignment, property right and reputation - analyze in the investigated regions}

When observing the information from the Central-Eastern region of Paraná, it is noted that path dependence and appropriated governance structure (formal contract) generate reputation and increase transaction frequency, promoting coordination costs (transaction) reduction (according to $P 1$ ). Measurement (by a third party, continued and with information 
RAUSP
56,4

Agents interviewed Highlights Analysis

Processor 1 “. . . there are 13.000 producers and we are unable to control and trust $100 \%$ in all"

Producer 1 "I don't trust the processor ... To improve my confidence, it would have to be more

Producer 2 transparency"

Producer 7

"I continue in the activity because I invested to produce quality milk and I get paid for that" "I invested in quality milk production and the payment for these attributes is guaranteed by the contract. So, I continue because of that"

Producer 1 "The buyer can take advantage of us because they fix the base price. So, when the product is not good on market, they lower the price"

Producer $4 \quad$ "Buyers can take advantage because they define the base price of milk. This relation is bizarre, we sell the product, but we don't define the price? And there is no negotiation?"

Processor 2 "It's not easy to switch buyers. ... Today, in the contractual scheme, the duration of the relationship is between 5 and 7 years. This change is difficult. The case of exchanging buyers is minimal"

Table $7 . \quad$ Producer 8 "Here it's not easy to change buyers. If a Highlights and analysis from interviews in the old Midi-Pyrénées

Source: Elaborated by the authors from primary data want to buy from him to make other producers afraid"

Reputation is not created between agents

The protection of additional milk price (legal right) encourages continuity in the activity

Opportunism due to the lack of economic rights protection

Difficulty of exchanging buyers

\section{Table 8.}

Property rights protection, reputation and effects in the old Midi-Pyrénées
Effect

Reduction of coordination

costs

Continuity of the relationship (contractual clauses)

\begin{tabular}{lll}
\hline Property rights protection & Reputation & Effect \\
\hline $\begin{array}{l}\text { Mandatory formal contract, } \\
\text { measurement, information sharing and }\end{array}$ & Not created & $\begin{array}{l}\text { Reduction of coordination } \\
\text { costs } \\
\text { institutional rules }\end{array}$ \\
$\begin{array}{l}\text { Continuity of the relationship } \\
\text { (contractual clauses) }\end{array}$
\end{tabular}

Source: Elaborated by the authors from primary data

distribution) responds to reputation in the relationship, which implies a reduction in coordination costs and positively influences the continuity of the relationship (according to P2). Increased returns are perceived by agents (individual performance) through superior quality milk production and reduced transaction costs, as a result of dimensions measured (guarantee of property rights) and reputation created (according to P3). In the old MidiPyrénées, the reputation has not been identified, the transaction continuity and its frequency result from contractual reasons (mandatory) and informal restrictions (agreement between processors). This makes it impossible for producers to replace buyers, indicating limits on the ability of the structure alone to get coordination improvements. Figure 2 summarizes the results in these two regions. 


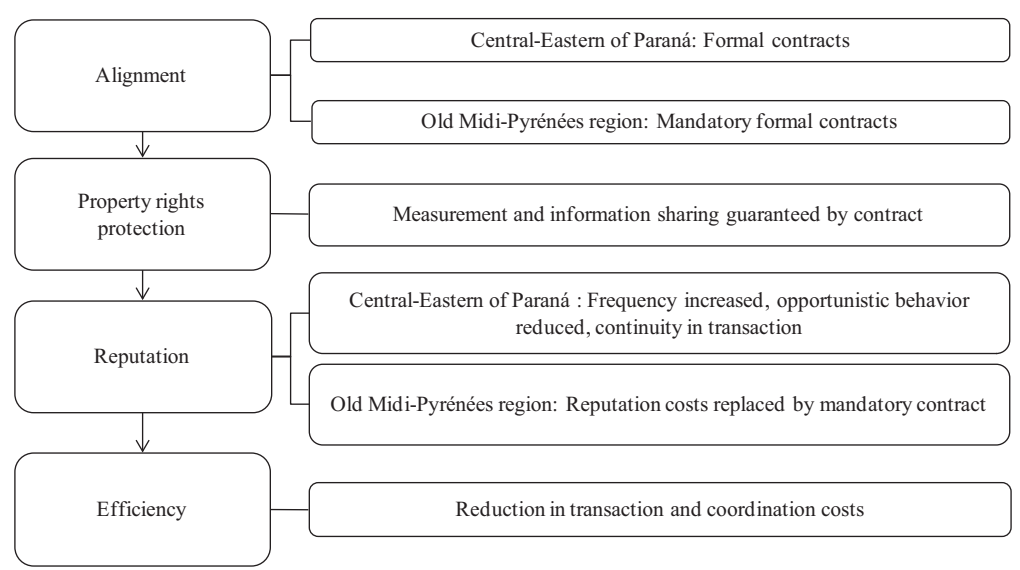

Source: Elaborated by the authors from primary data
Property rights and reputation

439

Figure 2.

Results in cases of efficiency generated

In the Western region of Paraná, reputation was identified due to path dependence, as discussed by North (1991) and it leads to an ongoing relationship between producers and cooperatives (according to P1). Measurement is performed on a recurring basis by a third party, but the information is partially distributed, which possibility processors value appropriation, limiting property rights protection (according to $P 2$ ). As low financial returns are made, as a result of minimal quality milk transacted, modest investments in production by the producer are identified (validating $P 3$ ).

In the Northern region of Paraná, reputation has not been found because there is a scenario of lack of confidence in measurement results, which is used to generate discounts in cases of non-compliance. The recurrence in transactions is not based on efficiency but is due to the low number of available and reliable processors for purchasing raw milk, which does not negate $P 1$. There is an absence of property rights protection (legal and economic) by processors, generating the possibility of the capture of individuals' rights (P2). The lack of rights protection and reputation reflects the inefficiency in the system, increase in transaction and measurement costs and less investment in production (P3). Figure 3 presents the results when property rights are partially protected, specific to Paraná (Western and Northern regions).

By relating empirical information with the theoretical assumptions presented, the propositions proved to be valid.

Regarding reputation created, it is noted that the reduction of opportunistic behavior and information sharing is directly linked to it. The frequency was also identified as a factor that influences reputation, but it can be associated with the governance structure established (a mandatory contract or lack of option). In cases where reputation has not been identified as previously existing, there are opportunistic attitudes in relationships and partial sharing of information, generated by measurement. The investment decision identified in conditions of structural alignment and reputation created shows that the performance is present when lack of rights protection and reputation is not present. 
\begin{tabular}{l} 
RAUSP \\
56,4 \\
440 \\
\hline
\end{tabular}

Figure 3.

Results in cases of limited property rights protection

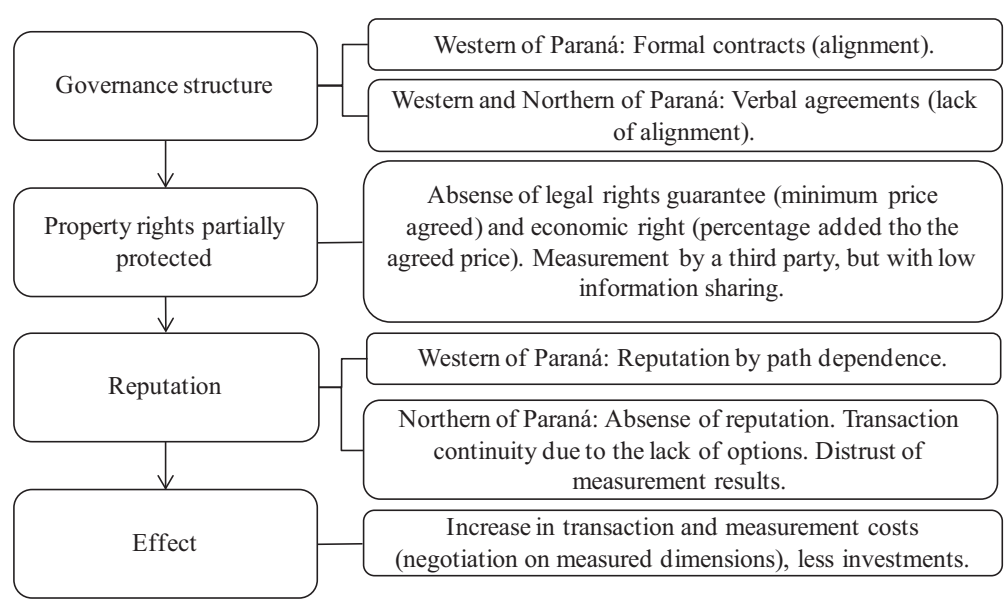

Source: Elaborated by the authors from primary data

Efficiency (reduction in transaction and coordination costs) and increases returns (superior quality milk) as a guideline was identified in cases where: property rights protection was effective; frequency was high (mandatory or not); reputation was present (Central-Eastern region of Paraná) or reputation costs were replaced by mandatory contract (old MidiPyrénées). It is important to note that in studied dairy AGS, measurement costs are present, due to milk specific characteristics and its variability that requires measurement in all collections, however, an increase in that costs could be identified (duplication of measurement). Where reputation was absent, higher measurement costs were anticipated (coordination, negotiation and retest).

Thus, the main proposition presented theoretically was ratified. Empirical research indicated that, in cases where efficiency is present (reduction in coordination and transaction costs), there is reputation and property rights protection through measurement and information sharing, as predicted by Barzel (2005), as well as governance structure alignment, as hypothesized by Williamson (1985).

\section{Conclusion}

This study aimed to understand the effects of measurement and reputation in property rights protection, in dairy AGS in Paraná, Brazil and Midi-Pyrénées, France. Qualitative research allows achieving this objective, supported by primary and secondary data, by using content analysis. As a result, it was possible to note that measurement positively influences property rights protection, as it generates information that, when shared, allows a better value distribution among the agents.

The statement that reputation leads to lower transaction costs was confirmed. Interviewed agents benefited by information generation and sharing, placed along with other aspects (reputation, path dependence, recurring frequency and governance structure alignment to attributes and dimensions), enjoy system improvement. Despite reducing transaction costs, it was noted that, in the studied AGS, reputation does not reduce measurement costs. Specific characteristics of milk and its dimensions require measurement in all collections, independent of existing reputation. 
Thus, the present study went on to understand efficiency through measurement, reputation and property rights protection. The study further explores the inter-segment relationship, with the application not only in agro-industrial chains but also in all businesses. The use of TCE and MCE theories together allows a better comprehension of the coordination of systems and the efficiency generation through opportunistic attitudes limited and property right protection. As such, improvements in the inter-segment relationship enhance gains across the entire system. These aspects must be considered, as the answer to environmental challenges is structuring efficient adaptation mechanisms, that need coordination.

As a limitation, the temporal context of data collection must be considered. In 2016, in France, the context was low prices, while in 2017, in Brazil, there was a rise in prices. This difference could have influenced some responses to the interviews, mainly about efficiency by producers. Thus, this limitation serves as an indication of future studies that deal with longitudinal research, following price and efficiency fluctuations on the part of respondents. Besides, the use of such theoretical complementarity must be advanced, to structure a robust proposal for theoretical integration of transaction costs and measurement, which would lead us to evolve in the explanation of why firms choose contract transactions. The role of institutions for strengthening relations in agribusiness, especially in cases of interdependence, needs to be deepened to define proposals and better understand the role of regulation for efficiency in these relations.

\section{References}

Auerbach, J. U., \& Azariadis, C. (2015). Property rights, governance, and economic development. Review of Development Economics, 19(2), 210-220, doi: https://doi.org/10.1111/rode.12138.

Augusto, C. A., Souza, J. P. D., \& Cário, S. A. F. (2017). Strategic contractual relationships in the automotive sector. Revista de Administração, 52(4), 443-455. doi: https://doi.org/10.1016/j. rausp.2017.08.006.

Barzel, Y. (1987). Knight 'Moral Hazard' theory of organization. Economic Inquiry, 117-120.

Barzel, Y. (1994). The capture of wealth by monopolists and the protection of property rights. International Review of Law and Economics, 14(4), 393-409. doi: https://doi.org/10.1016/01448188(94)90023-X.

Barzel, Y. (2001). A theory of organizations: to supersede the theory of the firm, Washington, DC: Department of Economics.

Barzel, Y. (2005). Organizational forms and measurement costs. Journal of Institutional and Theoretical Economics, 161(3), 357-373. doi: https://doi.org/10.1628/093245605774259291.

CNIEL - Centre National Interprofessionnel de l'economie laitière. (2019). L'économie laitière en chiffres, Édition 2019.

DRAAF Midi-Pyrénées. (2013). Bovins lait, n. 2. Retrieved from: http://draaf.occitanie. agriculture.gouv.fr/IMG/pdf/fiche_filieresBovins_laitGP_cle018adb.pdf (Acesso em 21 mai. 2020).

FAO. Food and Agriculture Organization. (2013). Market summaries: Milk and milk products. Retrieved from: www.fao.org/fileadmin/templates/est/COMM_MARKETS_MONITORING/Dairy/ Documents/November_2013.pdf (Acesso em 21 mai. 2020).

Farina, E. M. (1999). Competitividade e coordenação de sistemas agroindustriais: um ensaio conceitual. Gestão \& Produção, 6(3), 147 -161. doi: https://doi.org/10.1590/S0104-530X1999000300002.

Foss, K., \& Foss, N. J. (2001). Assets, attributes and ownership. International Journal of the Economics of Business, 8(1), 19-37. doi: https://doi.org/10.1080/13571510151075233. 
RAUSP

56,4

Guimarães, A. F., \& Bánkuti, S. M. S. (2019). Coordenação em sistemas agroalimentares diferenciados do café: uma revisão à luz da ECT e da ECM. Desafio Online, 7(1), 179-202.

IPARDES. Instituto Paranaense de Desenvolvimento Econômico e Social. (2009). Caracterização socioeconômica da atividade leiteira no paraná, Curitiba, PR.

Langlois, R. N. (1992). Transaction-cost economics in real time. Industrial and Corporate Change, 1(1), 99-127. doi: https://doi.org/10.1093/icc/1.1.99.

Macleod, W. B. (2007). Reputations, relationships and contract enforcement. Journal of Economic Literature, 45(3), 595-628. doi: https://doi.org/10.1257/jel.45.3.595.

Maison Du Lait. (2016). La filière française. Retrieved from: www.filiere-laitiere.fr/fr/chiffres-cles/filierelaitiere-francaise-en-chiffres (Acesso em 20 mai. 2020).

MAPA - Ministério de Agricultura. (2016). Pecuária e abastecimento: Instrução normativa n.76, de 23 de novembro de 2016. Retrieved from: www.gov.br/cgu/pt-br/assuntos/auditoria-e-fiscalizacao/ tomadas-de-contas-especiais/arquivos/in-71_modificada-pela-in-76.pdf (Acesso em: 01 abr. 2020).

Ménard, C. (2018a). Research frontiers of new institutional economics. RAUSP Management Journal, 53(1), 3-10. doi: https://doi.org/10.1016/j.rauspm.2017.12.002.

Ménard, C. (2018b). Organization and governance in the agrifood sector: How can we capture their variety? Agribusiness, 34(1), 142-160. doi: https://doi.org/10.1002/agr.21539.

Moraes, R. (1999). Análise de conteúdo. Revista Educação, 22(37), 7-32.

North, D. (1991). Institutions. Journal of Economic Perspectives, 5(1), 97-112. doi: https://doi.org/ 10.1257/jep.5.1.97.

Pereira, J. A., Bánkuti, S. M. S., Pereira, J. G., \& Souza, J. P. (2016). Transaçoes e garantias de direito de propriedade em sistemas agroalimentares: um estudo sobre a aquisição de leite cru por laticínios no estado do Paraná. Brasil. Espacios, 37(36), 22-32.

Popescu, A., \& Angel, E. (2009). Analysis of milk quality and its importance for milk processors. Lucrari Stiintifice Zootehnie si Biotehnologii, 42(1).

SEAB/DERAL. (2019). Análise da conjuntura agropecuária. Secretaria de estado da agricultura e do abastecimento, departamento de economia rural. Bovinocultura de leite. Retrieved from: www.agricultura.pr.gov.br/sites/default/arquivos_restritos/files/documento/201909/leite_2019_v1.pdf (Acesso em: 21 mai. 2020).

Trouvé, A., Dervillé, M., Gouin, D., \& Pouch, T. (2014). Étude sur les mesures contre les déséquilibres de marché: Quelles perspectives pour l'apprès quotas dans le secteur laitier européen? FranceAgrimer.

Williamson, O. E. (1985). The economic institutions of capitalism: firms, markets, relational contracting, New York, NY Press.

Williamson, O. E. (1993). Calculativeness, trust, and economic organization. The Journal of Law and Economics, 36(1, Part 2), 453-486. doi: https://doi.org/10.1086/467284.

Zylbersztajn, D. (2018). Measurement costs and governance: bridging perspectives of transaction cost economics. Caderno de Administração, 26(1), 1-19. doi: https://doi.org/10.4025/cadadm. v26i1.44220.

\section{Author has contributed in the following ways}

Sudré, Carolina Andrea Gómez Winkler. Conceptualization (Equal). Data curation (Equal). Formal analysis (Equal). Funding acquisition (Equal). Investigation (Equal). Methodology (Equal). Resources (Equal). Software (Equal). Supervision (Equal). Validation (Equal). Visualization (Equal). Writingoriginal draft (Equal). Writing-review \& editing (Equal). de Souza, José Paulo. Conceptualization (Equal). Formal analysis (Equal). Funding acquisition (Equal). Investigation (Equal). Methodology 
(Equal). Project administration (Equal). Supervision (Equal). Validation (Equal). Visualization (Equal). Writing-original draft (Equal). Writing-review \& editing (Equal). Bouroullec, Melise Dantas Machado. Conceptualization (Supporting). Investigation (Equal). Project administration (Equal). Resources (Equal). Software (Equal). Supervision (Equal).

Carolina Andrea Gómez Winkler Sudré can be contacted at: carolinagwinkler@gmail.com

Associate editor: Paula Schnaider

For instructions on how to order reprints of this article, please visit our website: 